\title{
RANCANG BANGUN SITUS RESPONSIF DI UNIVERSITAS BUANA PERJUANGAN KARAWANG DENGAN MENGGUNAKAN METODE PERPADUAN GRID SYSTEM DAN CSS MEDIA QUERY
}

\author{
Shofa Shofiah Hilabi, M.Kom \\ Universitas Buana Perjuangan Karawang, Sistem Informasi \\ shofashofia@gmail.com \\ Jl. H. S. Ronggowaluyo Telukjambe Timur Karawang 41361
}

\begin{abstract}
ABSTRAK
Peredaran tablet PC dan smartphone sudah tidak dapat dibendung lagi. Hampir setiap orang telah memilikinya. Peredaran yang luar biasa tersebut tentunya dipicu oleh inovasi yang dibuat oleh Apple saat mereka merilis $i P a d$ ke pasaran. Dan kini, teknologi tersebut tak henti-hentinya berkembang dan dipercaya telah menjadi salah satu dasar utama dalam evolusi PC ke depannya. Dalam dunia web development, dengan semakin meningkatnya penggunaan smartphone dan tablet ini, maka pembuatan web yang mobile - friendly juga semakin penting. Hampir semua klien khususnya perusahaan-perusahaan besar menginginkan situs mereka dapat diakses dengan baik di tablet dan smartphone. Situs responsif adalah suatu pendekatan teknologi yang menganjurkan pengembang situs web harus merespon kepada lingkungan dari pengguna berdasarkan ukuran layar, platform dan orientasi pengguna. Secara teknik pengembang situs web harus dapat memanfaatkan perpaduan antara flexible grids layout, gambar dan optimalisasi penggunaan CSS media queries. Misalnya pengguna beralih dari laptop ke iPad, maka situs tersebut harus secara otomatis berubah tampilan untuk mengakomodasi tampilan sesuai resolusi, ukuran gambar, dan kemampuan scripting. Dengan menggunakan teknologi ini kini para web developer tidak perlu membuat sebuah situs dalam dua versi (versi desktop dan mobile) bahkan situs responsif dapat menyesuaikan tampilan dengan gadget-gadget terbaru.
\end{abstract}

Kata kunci :, PC, Tablet, Laptop,Touch Pad, Portable, Stylus.Windows, Apple, Android

\section{PENDAHULUAN}

\subsection{Latar Belakang}

Dalam dunia web development, dengan semakin meningkatnya penggunaan smartphone dan tablet ini, maka pembuatan web yang mobile - friendly juga semakin penting. Hampir semua klien khususnya perusahaan-perusahaan besar menginginkan situs mereka dapat diakses dengan baik di tablet dan smartphone.Sebagai web developer yang harus terus menerus menyesuaikan dengan platform baru dan ukuran resolusi yang selalu berubah setiap saat, merancang situs dengan berbagai versi sangatlah tidak praktis, terlalu banyak tenaga yang harus dikerahkan dan waktu yang terbuang untuk membuat situs dalam berbagai versi. Apabila web developer hanya merancang satu versi situs hanya untuk desktop saja, maka otomatis situs tersebut kehilangan pengunjung yang mengakses internet melalui smartphone atau tablet. Atau apakah ada alternatif lain?

Situs responsif adalah suatu pendekatan teknologi yang menganjurkan pengembang situs web harus merespon kepada lingkungan dari pengguna berdasarkan ukuran layar, platform dan orientasi pengguna. Secara teknik pengembang situs web harus dapat memanfaatkan perpaduan antara flexible grids layout, gambar dan optimalisasi penggunaan CSS media queries. Misalnya pengguna beralih dari laptop ke iPad, maka situs tersebut harus secara otomatis berubah tampilan untuk mengakomodasi tampilan sesuai resolusi, ukuran gambar, dan kemampuan scripting. Dengan menggunakan teknologi ini kini para web developer tidak perlu membuat sebuah situs dalam dua versi (versi desktop dan mobile) bahkan situs responsif dapat menyesuaikan tampilan dengan gadget-gadget terbaru. Salah satu aspek yang paling menarik dari Situs responsif adalah dapat memberikan user experience yang baik di banyak perangkat dan berbagai ukuran layar. Ini merupakan karakteristik penting, karena web developer tidak mungkin untuk mengantisipasi semua perangkat dan ukuran layar yang digunakan oleh pencari untuk mengakses situs. Sebuah situs yang bekerja dengan baik terlepas dari variabel-variabel ini akan memberikan user experience yang lebih baik dan lebih konsisten daripada situs mobile yang terpisah yang dirancang untuk perangkat dan ukuran layar tertentu. Google menyatakan bahwa Selain itu, Google 
lebih memilih desain web responsif karena konten berada di satu situs dan satu URL sehingga lebih mudah bagi pengguna untuk berbagi, berinteraksi, dan link ke konten daripada konten yang berada pada situs mobile yang terpisah.Universitas Buana Perjuangan adalah salah satu sekolah tinggi teknologi yang bertempat di Jl.Raya HS.Ronggo Waluyo Teluk Jambe Karawang, Jawa Barat didirikan untuk memenuhi kebutuhan tenaga-tenaga ahli yang terdidik, terampil dan profesional di bidang teknik informatika, teknik industri, teknik mesin, dan lain-lain. Universitas Buana Perjuangan memerlukan situs web yang interaktif dan bisa diakses di berbagai perangkat sebagai media promosi agar menjangkau calon mahasiswa yang menggunakan prangkat mobile seperti smartphone dan tablet. Tampilan situs yang modern sesuai dengan kaidah web 2.0 diharapkan bisa meningkatkan animo pelajar untuk menuntut ilmu di Universitas Buana Perjuangan. Dengan demikian akhirnya penulis melakukan penelitian yang berjudul "RANCANG BANGUN SITUS RESPONSIF DI UNIVERSITAS BUANA PERJUANGAN KARAWANG DENGAN MENGGUNAKAN PERPADUAN GRID SYSTEM DAN CSS MEDIA QUERY". Adapun umusan Masalahnya adalah tahap perencanaan yaitu bagaimana menampilkan situs responsif yang menarik sesuai kaidah web 2.0,tahap analisa yaitu bagaimana perpaduan grid layout dan CSS media query memberikan solusi dalam permasalahan adaptasiberbagai platform dan resolusi layar?, tahap perancangan, Bagaimana menerapkan teknik grid system layout untuk menampilkan user interface yang tertata rapi dan memiliki estetika tampilan situs yang baik,tahap coding, Bagaimana menerapkan teknik pembuatan situs responsif Universitas Buana Perjuangan dengan menggunakan bahasa pemograman situs terkini CSS3 dan HTML5 dan mengoptimalkan jQuery untuk akses situs yang lebih cepat,dan terakhir tahap pengujian, Bagaimana situs Universitas Buana Perjuangan dapat berjalan di berbagai tampilan browser terkini maupun browser versi lama. Sedangkan ruang lingkup masalah adalah penulis merancang situs Universitas Buana Perjuangan dengan memanfaatkan pustaka jQuery dan tampilan yang responsif dan waktu loading yang cepat sehingga calon mahasiswa bisa mengakses situs Universitas Buana Perjuangan dari berbagai perangkat dan gadget terkini, serta pembahasan masalah akan fokus kepada bagaimana mengimplementasikan situs responsif dengan menggunakan grid layout dan CSS Media Query.

\subsection{Tujuan Penelitian}

Tujuan dari penelitian ini adalah untuk enerapkan teknologi terbaru situs web yang responsif dan menjadikan standar baru dalam dalam pembuatan situs web.yang kedua Optimalisasi konten situs web yang dapat menyesuaikan tampilan di berbagai ukuran layar dan browser, yang ketiga menampilkan situs resmi Universitas Buana Perjuangan yang mengacu pada kaidah web 2.0 dan RWD (Responsive Web Design), serta menampilkan situs dengan akses load yang relatif singkat dan efisien.

\section{II.Tinjauan Pustaka}

\subsection{Desain Situs Responsif}

Situs menurut Ed Tittel dalam bukunya HTML, XHTML \& CSS for Dummies, Situs adalah kumpulan halaman yang bisa mengakomodasi informasi data teks, data gambar diam atau gerak, data animasi, suara, video dan atau gabungan dari semuanya, baik yang bersifat statis maupun dinamis yang membentuk satu rangkaian bangunan yang saling terkait dimana masing-masing dihubungkan dengan jaringan-jaringan halaman (hyperlink). Bersifat statis apabila isi informasi website tetap, jarang berubah, dan isi informasinya searah hanya dari pemilik website. Bersifat dinamis apabila isi informasi website selalu berubah-ubah, dan isi informasinya interaktif dua arah berasal dari pemilik serta pengguna website. Sedangka definisi Desain Situs Responsif menurut Annie Pilon, Desain Situs Responsif adalah pendekatan dimana seorang desainer web/programer membuat halaman web yang "merespon kepada" atau berubah sendiri tergantung dari tipe gadget atau PC yang digunakan.

\subsection{Lima Komponen Situs Responsif}

Menurut Brian Schwartz, ada 5 komponen yang harus diperhatikan ketika merancang Situs Responsif adalah Navigasi, Coloum, Call to Action, Branding, Padding dan White Space

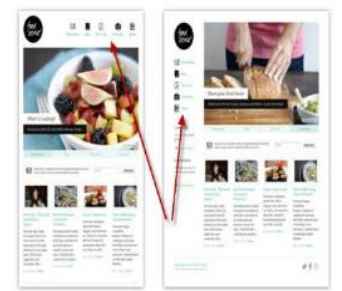

Gbr. 2.1 Navigasi

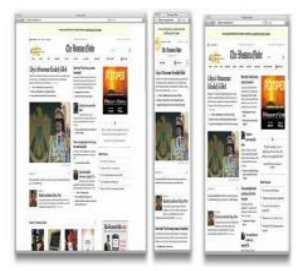

Gbr. 2.2 Coloum Gambar 


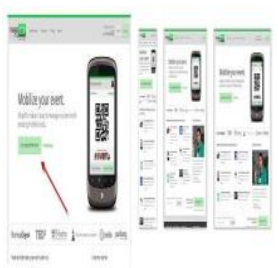

Gbr. 3.3. Action Gambar Call To Action

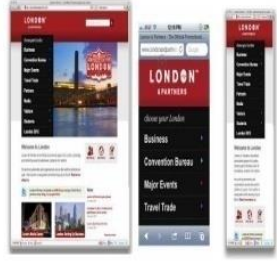

Gbr. 3.4 White-Sp

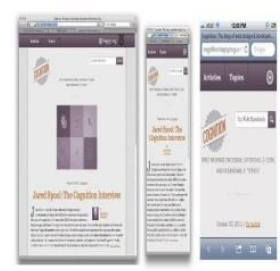

Gbr. 3.5 Padding \& White Space

\subsection{Cascading Style Sheets (CSS)}

Menurut Richard York, Cascading style sheets (CSS) adalah bahasa pemograman yang bertujuan untuk menyederhanakan desain dan pengembangan web. Singkatnya, CSS menangani tampilan dari situs. CSS bukan merupakan bahasa pemograman. Sama halnya styles dalam aplikasi pengolahan kata seperti Microsoft Word yang dapat mengatur beberapa style, misalnya heading, subbab, bodytext, footer, images, dan style lainnya untuk dapat digunakan bersama-sama dalam beberapa berkas (file). Pada umumnya CSS dipakai untuk memformat tampilan halaman web yang dibuat dengan bahasa HTML dan XHTML. CSS dapat mengendalikan ukuran gambar, warna bagian tubuh pada teks, warna tabel, ukuran border, warna border, warna hyperlink, warna mouse over, spasi antar paragraf, spasi antar teks, margin kiri, kanan, atas, bawah, dan parameter lainnya. CSS adalah bahasa style sheet yang digunakan untuk mengatur tampilan dokumen. Dengan adanya CSS memungkinkan kita untuk menampilkan halaman yang sama dengan format yang berbeda.

\subsection{Layout Dan Grid System}

Layout adalah penyusunan dari elemen-elemen desain yang berhubungan kedalam sebuah bidang sehingga membentuk susunan artistik. Hal ini dapat juga disebut manajemen bentuk dan bidang. Tujuan utama layout adalah menampilkan elemen gambar dan teks agar menjadi komunikatif dalam sebuah cara yang dapat memudahkan pembaca menerima informasi yang disajikan.

\subsection{Grid System}

Sebuah grid diciptakan sebagai solusi terhadap permasalahan penataan elemen-elemen visual dalam sebuah ruang. Grid systems digunakan sebagai perangkat untuk mempermudah menciptakan sebuah komposisi visual. Melalui grid system seorang perancang grafis dapat membuat sebuah sistematika guna menjaga konsistensi dalam melakukan repetisi dari sebuah kompisisi yang sudah diciptakan. Tujuan utama dari penggunaan grid systems dalam desain grafis adalah untuk menciptakan suatu rancangan yang komunikatif dan memuaskan secara estetik.

\subsection{CSS Media Query}

Media Query meliputi tipe dari media dan mengekspresikan batasan dari style sheets dengan menggunakan fitur media, seperti lebar, panjang, dan warna. Media queries, yang ditampilkan pada CSS3, memungkinkan pengaturan isi situs sehingga dapat beradaptasi dengan ukuran layar yang diinginkan tanpa harus mengubah isi dari situs tersebut. CSS3 Media Queries Syntax Media queries meliputi tipe media dan dan termasuk spesifikasi CSS3, meliputi satu pernyataan atau lebih, dinyatakan sebagai fitur-fitur media menghasilkan deklarasi true atau false. Hasil query adalah true jika tipe media yang dikhususkan dalam media query cocok dengan tipe perangkat yang ditampilkan dalam dokumen dan semua pernyataan dalam media adalah true.

\subsection{Web 2.0}

Web 2.0. digunakan untuk menggambarkan aplikasi-aplikasi Internet generasi baru yang merevolusi cara kita menggunakan Internet. Semua aplikasi ini membawa kita masuk ke babak baru penggunaan Internet yang berbeda dengan generasi sebelumnya.Web 2.0 dan Situs Responsif Saat ini Web 2.0 adalah tentang bagaimana menjadikan sebuah situs yang tadinya statis menjadi lebih interaktif dan responsif. Sepertinya sangat sederhana, tetapi hal tersebut tidak mungkin diaplikasikan sebelum ditemukan HTML5 dan CSS3 beberapa tahun ini. Artinya seperti desktop applications yaitu mudah digunakan.Situs responsif memberikan jalan bagi suatu situs untuk lebih bisa diakses oleh berbagai pengguna dari berbagai macam perangkat. Sebuah situs harus didesain sesederhana mungkin supaya memudahkan pengguna untuk mengaksesnya. Dan itulah esensi dari Web 2.0 dan situs responsif.

\subsection{JavaScript dan JQuery}

JavaScript adalah bahasa yang digunakan untuk membuat program yang digunakan agar dokumen HTML yang ditampilkan dalam browser menjadi lebih interaktif, tidak sekedar indah saja. JavaScript 
memberikan beberapa fungsionalitas ke dalam halaman web, sehingga dapat menjadi sebuah program yang disajikan dengan menggunakan antarmuka web. Pengertian jQuery adalah sebuah pustaka JavaScript yang menekankan pada interaksi antara JavaScript dan HTML. Pustaka ini dirilis pada Januari 2006 di BarCamp NYC oleh John Resig dan berlisensi ganda di bawah Lisensi MIT dan GPL. Microsoft dan Nokia telah mengumumkan akan mengemas jQuery di platform mereka. Microsoft awalnya mengadopsinya dalam Visual Studio untuk digunakan dalam ASP.NET AJAX dan ASP.NET MVC Framework, sedangkan Nokia akan mengintegrasikannya dalam kerangka Web Run-Time.

\subsection{Desain Interaksi}

Desain interaksi berarti membangun suatu produk yang dapat digunakan, artinya mudah untuk dipelajari, efektif digunakan, dan terasa nyaman bagi penggunanya. Perancang desain interaksi memerlukan pengetahuan tentang pengguna, teknologi dan interaksi antara keduanya untuk menciptakan pengalaman pengguna yang efektif.

\subsection{UML}

UML (Unified Modeling Language) adalah sebuah bahasa yang berdasarkan grafik / gambar untuk memvisualisasi, menspesifikasikan, membangun, dan pendokumentasian dari sebuah sistem pengembangan software berbasis OO (Object-Oriented). UML sendiri juga memberikan standar penulisan sebuah system blue print, yang meliputi konsep bisnis proses, penulisan kelas-kelas dalam bahasa program yang spesifik, skema database, dan komponen-komponen yang diperlukan dalam sistem software. meliputi konsep bisnis proses, penulisan kelas-kelas dalam bahasa program yang spesifik, skema database, dan komponen-komponen yang diperlukan dalam sistem software. UML sendiri terdiri atas pengelompokkan diagram-diagram sistem menurut aspek atau sudut pandang tertentu. Diagram adalah yang menggambarkan permasalahan maupun solusi dari permasalahan suatu model. UML mempunyai 9 diagram, yaitu; use case, class, object, state, sequence, collaboration, activity, component, dan deployment diagram.

\section{METODE PENELITIAN}

Metode Penelitian yang digunakan dalam penelitian ini adalah dimulai dari metode pengumpulan data dan metode pengembangan Perangkat Lunak. Metode pengumpulan data yang dilakukan adalah metode studi literatur yang dilakukan untuk mengumpulkan data yang diperoleh dari artikel, buku, jurnal dll, untuk menggali teori-teori yang telah berkembang dalam bidang ilmu yang terkait, mencari metodemetode serta teknik penelitian baik dalam mengumpulkan data maupun dalam menganalisis data yang dilakukan melalui peneliti-peneliti terdahulu serta memperoleh orientasi yang lebih luas dalam permasalahan yang dipilih serta menghindari duplikasi-duplikasi yang tidak diinginkan (Nazir, 2003, dalam Budi,2009).(studi lapangan), wawancara,yaitu Metode wawancara dilakukan dengan cara mewawancarai mahasiswa, dosen dan staf Universitas Buana Perjuangan terkait masalah situs UBP. Sasaran isi wawancara yaitu memperoleh informasi tentang seberapa efisienkah tampilan situs UBP sehingga informasi utama dapat ditampikan secara maksimal dengan tidak memperbesar dan memperkecil tampilan situsnya. Kesimpulan dari wawancara berusaha meningkatkan beberapa pandangan tentang apa yang ada di situs UBP dan informasi penting apa yang bisa dilihat melalui perangkatt teknologi informasi lainnya selain PC(Personal Komputer). Sedangkan metode pengembangan perangkat lunak yang digunakan adalah metode WaterFall. Menurut R. S. Pressman (2002, p86-88), Model siklus hidup (life cycle model) adalah model utama dan dasar dari banyak model. Salah satu model yang cukup dikenal dalam dunia rekayasa perangkat lunak adalah the waterfall model. Ada 5 tahapan utama dalam the waterfall modelseperti terlihat pada Gambar di bawah ini. Disebut waterfall (berarti air terjun) karena memang diagram tahapan prosesnya mirip dengan air terjun yang bertingkat adapun tahap-tahapnya sebagai berikut:

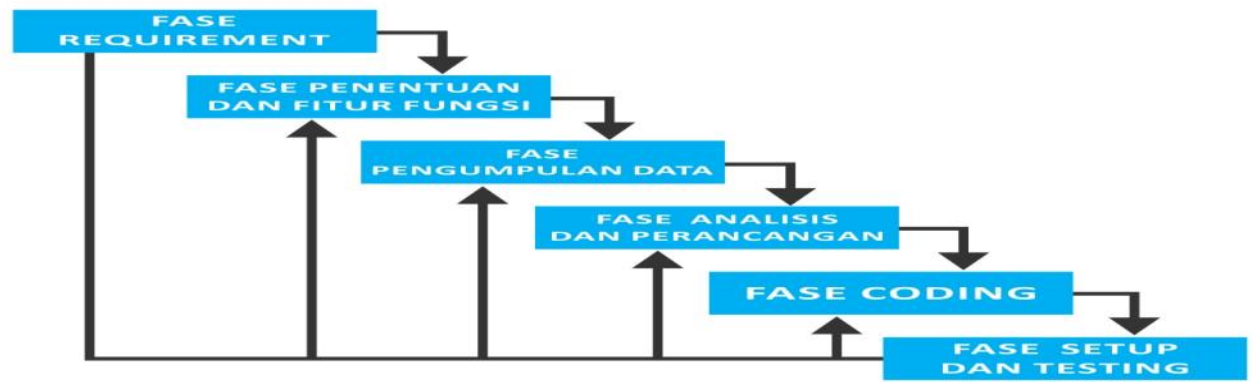

Gambar 3.1 Metode waterfall (Pressman, Roger S. 2002)

\subsection{Fase-fase Waterfall}


Pada fase ini penulis menyusun dan mempersiapkan apa saja yang diperlukan dari sebuah situs perguruan tinggi yaitu: Navigasi situs yang mudah diakses; Informasi Kontak yang mudah ditemukan;Tujuan dari situs yang dibuat dan apa yang ingin dicapai.Situs yang dibuat harus bisa mempromosikan universitas Buana Perjuangan khususnya kepada pengguna tablet dan smartphone Pada rancang bangun situs ini, penulis mengambil referensi dan inspirasi dari situs resmi Universitas Cambridge http://www.cam.ac.uk/ dimana situs tersebut sudah mengadaptasi kaidah web 2.0 dan situs responsif..Fase Penentuan dan Fitur Fungsi meliputi meliputi penentuan fitur-fitur situs terkini sesuai dengan kaidah web 2.0 sebagai berikut:Di desain untuk performa dan waktu load yang singkat;Kompatibel dengan browser terkini maupun browser lama;Mempunyai layout yang fleksibel;Responsif Web Design. Fase pengumpulan ata Setelah melalui fase diatas data maka penelitian dilanjutkan dengan proses sebagai berikut;Mencari ide dan inspirasi tampilan situs;Mempersiapkan bahan-bahan seperti icon, logo, button dan lain-lain;Merinci software-software dan bahasa pemograman yang akan digunakan. Fase Analisis dan Perancangan yaitu sebelum memulai proses perancangan, terlebih dahulu penulis melakukan analisis terhadap perkembangan ukuran layar dari berbagai perangkat. Pada saat ini ukuran layar sangat banyak dan variatif, dimulai ketika Steve Jobs memperkenalkan Apple, maka vendor -vendor yang lain berlombalomba untuk membuat perangkat mobile yang praktis dengan ukuran layar yang berbeda-beda.

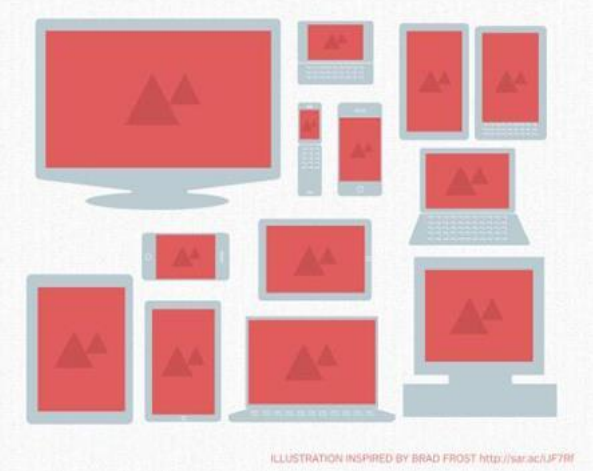

Gambar 3.2 Variasi ukuran layar

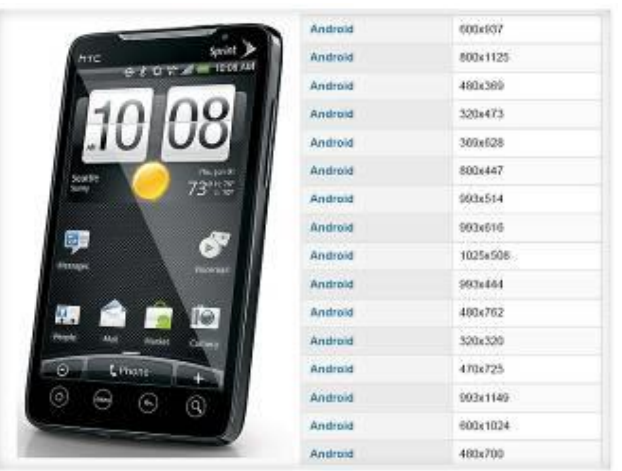

Gambar 3.3 Smartphone Android dengan ukuran layar

Kemudian disusul Android dengan vendor yang berbeda-beda sehingga ukuran layar pun semakin banyak dan beragam. Dalam perancangan situs responsif, ukuran layar dapat diwakilkan menjadi tiga ukuran dasar yaitu: Desktop; Tablet/iPad; Smartphone.Jadi dalam proses perancangan, penulis cukup merancang tampilan untuk tiga perangkat diatas karena media query bisa mewakili ukuran-ukuran layar dimulai dari ukuran layar terkecil (smartphone) sampai ukuran yang paling besar (desktop) dan ukuranukuran layar yang ada diantara keduanya.

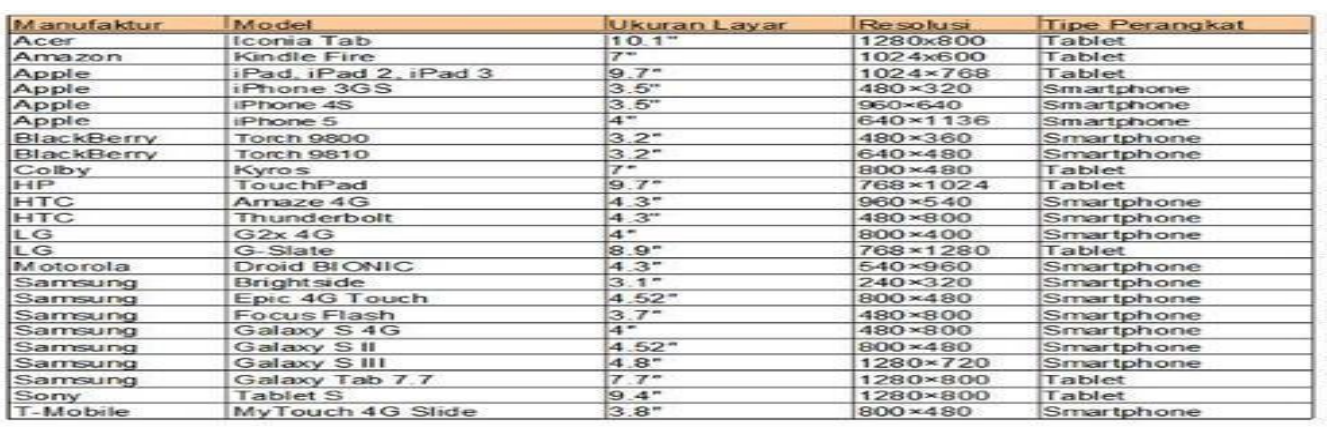




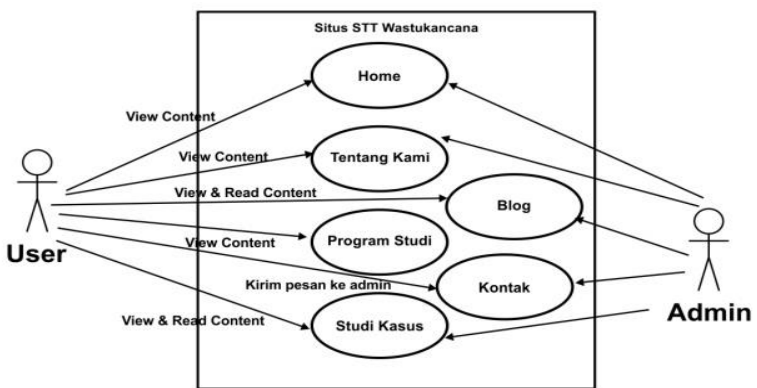

Tabel 3.2 Tabel ukuran layar dan resolusi
Gambar 3.4 Use Case Diagram

Fase Perancangan yaitu Use Case Diagram urutan utama use case menjelaskan urutan interaksi yang paling umum antara aktor dan sistem. Dimana aktor disini adalah pengakses situs yang menggunakan berbagai macam perangkat dari handphone, smartphone, sampai laptop. Pengakses situs Universitas Buana Perjuangan bisa memanfaatkan fitur situs yang responsif dan berinteraksi dengan system yang dibangun didalam situs diantaranya: Mengakses situs;Mendaftar online;Mengisi kuesioner; Sedangkan administrator atau pengembang web bertugas untuk menangani: Desain interface, situs, Coding, Update konten situs, Menangani pendaftar online

\subsection{Perancangan Situs Responsif}

Situs desain responsif menampilkan 3 layout untuk bisa mengadaptasi tampilan berbagai resolusi layar, maka dibuat draft dengan 3 layout sekaligus seperti gambar dibawah ini:

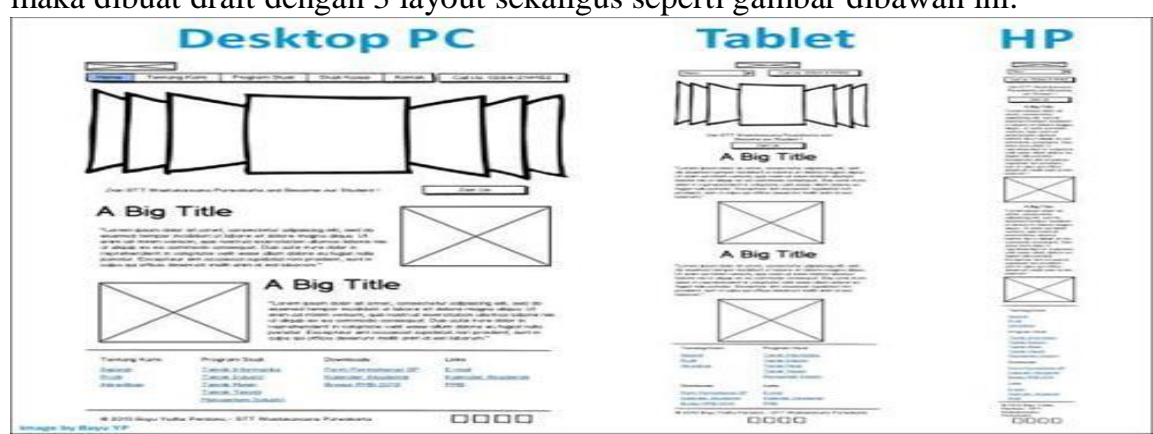

Gbr. 3.10 Rancangan Layout

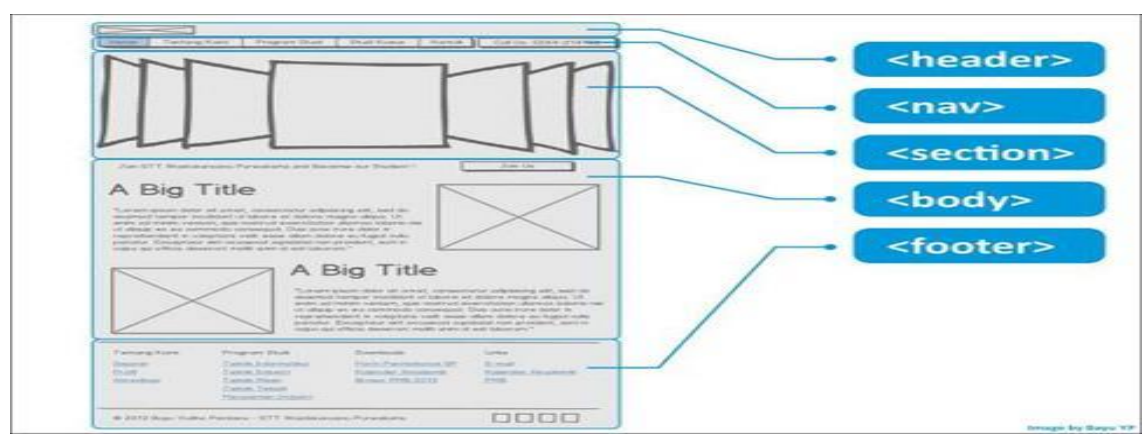

Gbr 3.11 Pembagian draft dasar untuk coding

Desain layar desktop adalah draft dasar dari rancangan,sedangkan untuk draft layout tablet dan handphone, ada perubahan pada menu navigasi, jQuery Slideshow, dan beberapa penyesuaian pada footer, untuk jQuery slideshow pada layout HP tidak ditampilkan karena layar HP terlalu kecil dan akan mengakibatkan waktu loading yang cukup lama. Sebelum membuat layout di photoshop, layout draft dasar dibagi menjadi 5 bagian yaitu header, navigation, seaction, body, dan footer. Hal ini untuk mempermudah saat proses coding. Seperti pada gambar $3.11 \mathrm{di}$ atas. 


\section{HASIL DAN PEMBAHASAN}

\subsection{Batasan Implementasi}

Batasan Implementasi adalah Implementasi adalah tahapan lanjut dari sistem yang dirancang, dalam perancangan situs ini tahapan tersebut disebit fase setup dan testing. Fase Setup dan TestingSetelah perancangan situs selesai maka dilakukan proses testing browser compatibility dan responsiveness situs secara offline dengan software Adobe Dreamweaver CS6. Setelah proses tes tersebut selesai, situs di upload ke jasa layanan hosting berbayar dengan domain Shofa.hilabi@ubpkarawang.ac.id dengan sub domain http:/ubpkarawang.ac.id Domain tersebut hanya bersifat sementara karena diperlukan tes yang berkelanjutan secara online untuk mebuktikan situs tersebut sudah responsif atau masih statis dan apakah media query sudah diterapkan dengan tepat.

\subsection{Lingkungan Implementasi}

\section{Spesifikasi Hardware dan Software yang digunakan}

Untuk dapat membuat situs responsif ini di butuhkan perangkat hardware dan software. Penulis menggunakan spesifikasi komputer adalah Hardware Processor AMD FX 6100 6-Core,RAM 8 GB, Monitor layar 22 Inch 1080 pixel Full HD (Mewakili resolusi untuk desktop), VGA Card AMD Radeon HD6870 1 GB,Wacom Tablet Intuos 4,Smartfren Andromax Tab 7.0 (Mewakili resolusi untuk tablet), Acer Aspire One 532h-2Bb (Mewakili resolusi untuk netbook), iPhone 4 (Mewakili resolusi untuk smartphone),Nokia C3 (Mewakili mobile phones),Software terdiri dari Sistem Operasi Microsoft Windows XP dan Windows 7,Balsamiq Mockups;Adobe Dreamweaver CS6;Adobe Photoshop CS6;Filezilla;Browser Internet terkini untuk test;Adobe Illustrator CS6;Corel Draw X6;Adobe Fireworks CS3;Sublime Text 2. Sedangkan Spesifikasi Minimum Hardware dan Software untuk User Spesifikasi minimum untuk mengakses situs responsif ini adalah sebagai berikut: Hardware: PC Processor minimal Pentium III dan memory 512 mb;Handphone;Nokia N73 atau merk lain dengan spesifikasi yang sama dengan tampilan layar minimal 256 ribu keatas.;Smartphone dan Tablet; Semua jenis Tablet dan Smartphone dengan tampilan layar 256 ribu keatas; Software terdiri dari Sistem Operasi

Sistem operasi yang mendukung tampilan situs responsif adalah sebagai berikut: Windows XP; Windows Vista;Windows 7;Windows 8;Linux;iOS;Mac OS;Android;Windows Phone;Blackberry OS; Browser ( Firefox 3.5 keatas,Internet Explorer 9.0 keatas,Chrome 5.0 keatas,Safari 4.0 keatas,Opera 9.5 keatas,iOS Safari 3.2 keatas,Opera Mini 5.0 keatas,Opera Mobile 10.0 keatas;,Android Browser 3.0 keatas,

\subsection{Tampilan Antarmuka}

\section{Halaman Depan (Home)}

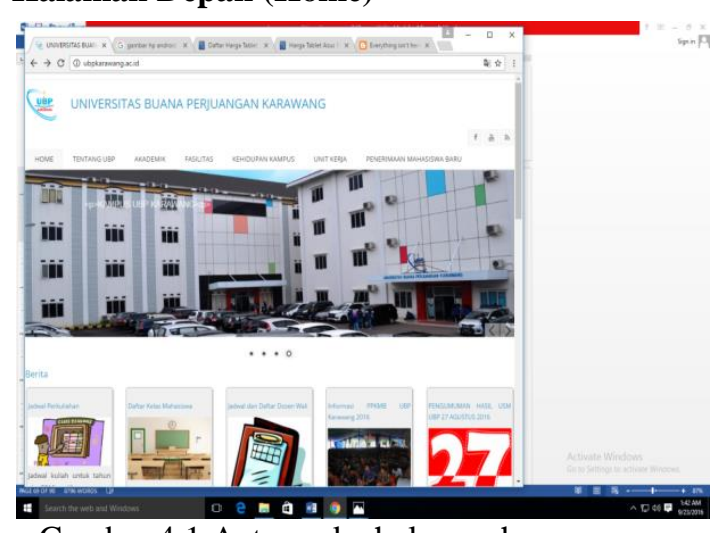

Gambar 4.1 Antarmuka halaman home. Halaman Profil

\section{Halaman Sejarah}

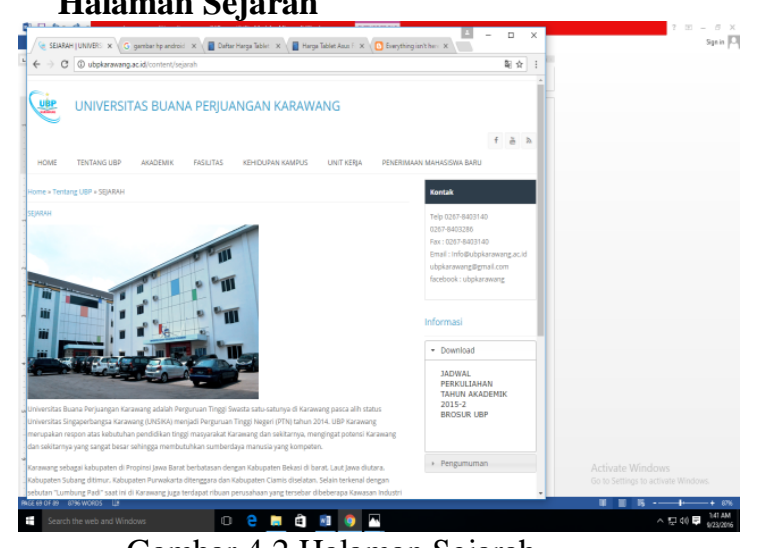

Gambar 4.2 Halaman Sejarah 


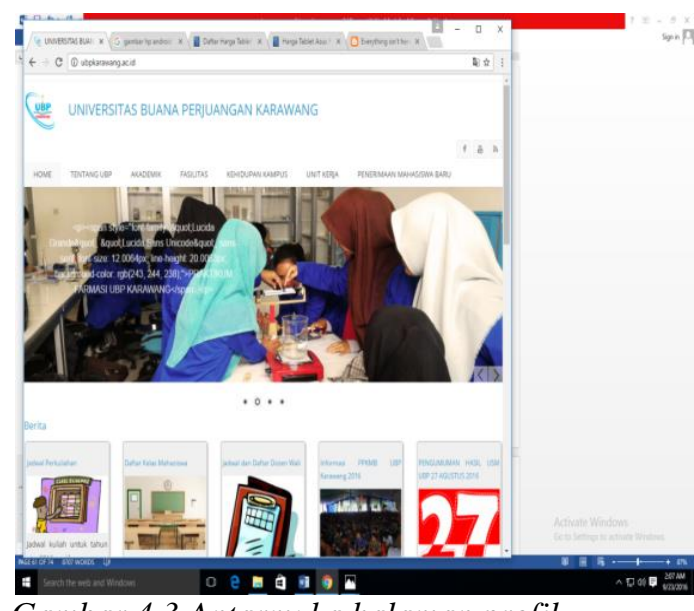

Gambar 4.3 Antarmuka halaman profil

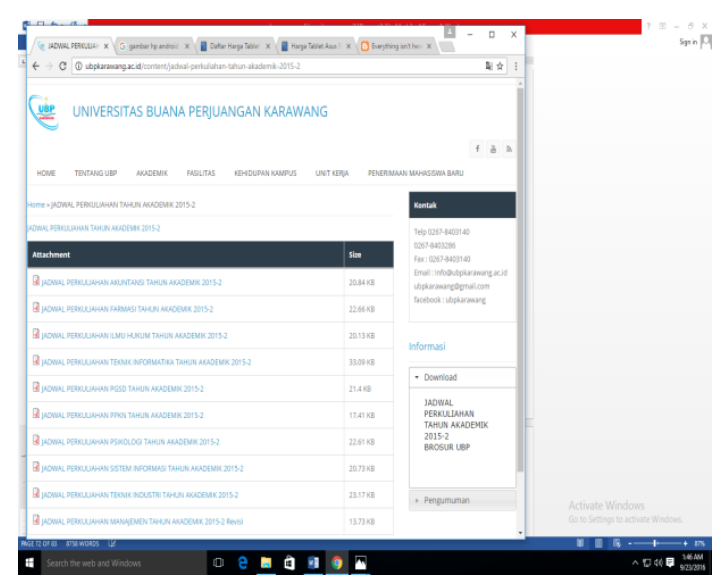

Gambar 4.4 Antarmuka halaman Studi Kasus.

\subsection{Browser Compatibility Testing}

Setelah semua halaman situs diupload ke web hosting dilanjutkan ke tahap Browser Compatibility Testing dimana alamat situs yaitu shofa.ubpkarawang.ac.id di tes kompatibilitasnya terhadap browserbrowser populer di http://browsershots.org.

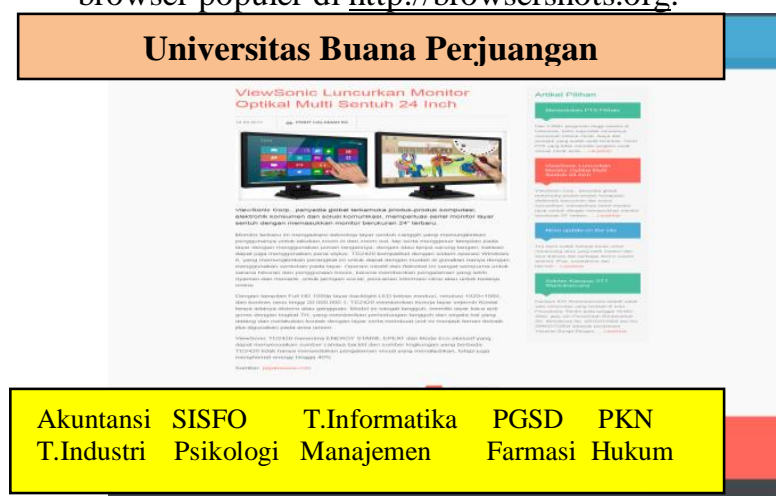

Gambar 4.5 Browser Compatibility Testing

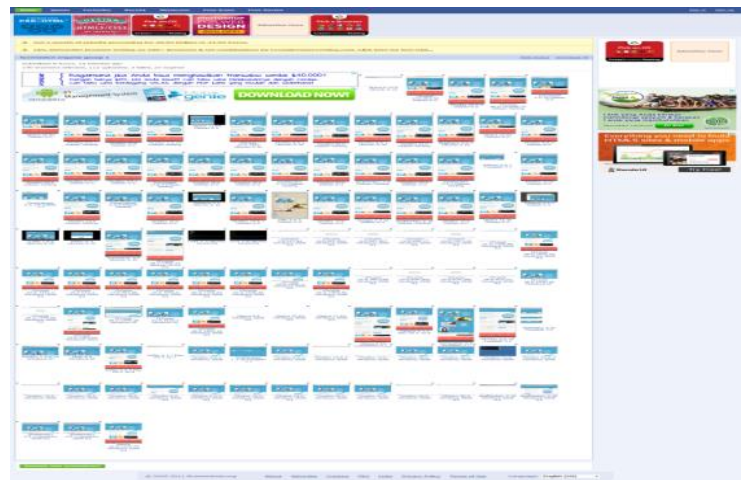

Gambar 4.6 Tampilan Antarmuka Blog lengkap

\section{V.KESIMPULAN}

Kesimpulan dari peneltian ini adalah setelah proses perancangan dan implementasi selesai, maka pembuatan situs responsif dengan metode grid system dan CSS3 Media Query pada Universitas Buana Perjuangan Karawang ini memberi manfaat kepada penulis dalam banyak hal dan penulis dapat memberikan kesimpulan sebagai berikut: Dapat mengembangkan pengetahuan yang berhubungan dengan pemograman web;Halaman web dapat diakses oleh berbagai perangkat terkini; Situs Universitas Buana Perjuangan Karawang kini memiliki situs yang sesuai dengan kaidah web 2.0;Memiliki suatu situs yang dapat menyesuaikan dengan tren terkini dimana semakin banyak pengakses internet yang menggunakan mobile device untuk mengakses situs dapat meningkatkan promosi dari situs tersebut;Untuk pengembangan selanjutnya penulis akan mengembangkan metode grid system dan media query dengan bahasa pemograman php dan ajax untuk mengaktifkan form pendaftaran online dan kontak di situs Universitas Buana PerjuanganKarawang. Sedangkan saran yang kiranya dapat bermanfaat bagi pengguna dan web developer yaitu: Universitas Buana Perjuangan sebaiknya mempekerjakan seorang administrator web khusus untuk merancang dan mengembangkan situs web di Universitas Buana Perjuangan Karawang;Dalam perancangan suatu halaman web diperlukan minimal skill desain grafis yang memadai untuk memenuhi permintaan klien-klien besar; Untuk proses perkuliahan, sebaiknya hindari CMS untuk mengasah skill coding dan perancangan web yang tepat dan selalu up to date;CMS perlu juga dipelajari tetapi pembuatan web secara hand coding dari awal dapat mengasah skill pemograman web dari web designer itu sendiri. 


\section{DAFTAR PUSTAKA}

Andrew, Rachel. "The CSS3 Anthology: Take Your Sites to New Heights"Collingwood: Que Publishing, 2012.

A.S, Rosa., Shalahudin.M, "Modul Pembelajaran Rekayasa Perangkat Lunak (Terstruktur dan Berorientasi Objek"), Modula, Bandung, 2011.

Burgess, Andrew, "Getting Good with JavaScript. Oshawa: Rockable Press", 2011

Goldstein, "HTML5 \& CSS3 for the Real World". Collingwood: Sitepoint, 2011.

Kadlec, "Implementing Responsive Design", California: New Riders, 2013

Marcotte, "Responsive Web Design", New York: A Book Apart, 2012

Tittel, Ed \& Noble, Jeff. Hoboken: Wiley Publishing, Inc "HTML, XHTML \& CSS for Dummies". 2008 York, Richard, "Beginning Css Cascading Style Sheets for Web Design", Indianapolis",

Wiley Publishing, IncAbdon, Jose, "UML (Unified Modeling Language)" http:// joseabdon41155055100078.blogspot.com/2013/05/uml.html diakses, 20 Maret 2016.

Far, Pierre. 2012. "Recommendations for building smartphone-optimized websites"http:// googlewebmastercentral.blogspot.com/2012/06/recommendations-for-building-smartphone.html diakses 20 Maret 2016.

Devi, Susanti, Ratna, "Apa itu web 2.0" http://ratnadevisusanti16.wordpress.com/ diakses 2, 20 Maret 2016.

Hakim, Zainal."Mengenal Layout Desain" http://www.zainalhakim.web.id/posting/mengenal-layoutdesain.html diakses 20 Maret 2016.

Mozilla Developer Team. 2012. "CSS Media Querys" https://developer.mozilla.org/en-US/docs/ Web /Guide/ CSS/Media queries diakses 24 Maret 2016.

Pilon, Annie. 2013. “What is Responsive Web Design?” http://smallbiztrends.com/2013/05/ what-isresponsive-web-design.html diakses 18 Maret 2016.

Putra, Trinadi, 2012. "Pengenalan Unified Modelling" , http://trinadi-putra.blogspot.com /2012/04/pengenalan-unified-modelling.html diakses 20 Maret 2016.

“jQuery Introduction”, http://www.w3schools.com/jquery/jquery_intro.asp diakses 20 Maret 2016.

Schwartz, Brian. 2013. "5 Key Responsive Web Design Elements", http://blog.crazyegg.com/2011/ 11/14/responsive-web-design-elements/ diakses 25 Maret 2016.

Tranfici, Annarita, 2013. "Understanding Responsive Web Design: Cross-browser Compatibility" http://www.sitepoint.com/understanding-responsive-web-design-cross-browser-compatibility/ diakses 20 Maret 2016.

Zeldman, Jeffrey. 2012. "Ethan Marcotte on Responsive Web Design " http://www.netmagazine.com/interviews/ethan-marcotte-responsive-web-design diakses 25 Maret 2016. Andrew, Rachel. "The CSS3 Anthology: Take Your Sites to New Heights"Collingwood: Que Publishing, 2012.

A.S, Rosa., Shalahudin.M, "Modul Pembelajaran Rekayasa Perangkat Lunak (Terstruktur dan Berorientasi Objek"), Modula, Bandung, 2011.

Burgess, Andrew, "Getting Good with JavaScript. Oshawa: Rockable Press", 2011

Goldstein, "HTML5 \& CSS3 for the Real World". Collingwood: Sitepoint, 2011.

Kadlec, "Implementing Responsive Design", California: New Riders, 2013

Marcotte, "Responsive Web Design", New York: A Book Apart, 2012

York, Richard, "Beginning Css Cascading Style Sheets for Web Design", Indianapolis",Wiley Publishing, IncAbdon, Jose, "UML (Unified Modeling Language)" http:// joseabdon41155055100078. blogspot.com/2013/05/uml.html diakses, 20 Maret 2016.

Far, Pierre. 2012. "Recommendations for building smartphone-optimized websites"http ://googlewebmastercentral.blogspot.com/2012/06/recommendations-for-building-smartphone.html diakses 20 Maret 2016.

Hakim, Zainal."Mengenal Layout Desain" http://www.zainalhakim.web.id/posting/mengenal-layoutdesain.html diakses 20 Maret 2016. Mozilla Developer Team. 2012. "CSS Media Querys" https: //developer.mozilla.org/en-US/docs/Web/Guide/CSS/Media queries diakses 24 Maret 2016.

Schwartz, Brian. 2013. "5 Key Responsive Web Design Elements", http://blog.crazyegg.com/2011/ 11/14/responsive-web-design-elements/ diakses 25 Maret 2016.

Tranfici, Annarita, 2013. "Understanding Responsive Web Design: Cross-browser Compatibility" http://www.sitepoint.com/understanding-responsive-web-design-cross-browser-compatibility/ diakses 20 Maret 2016.

Zeldman, Jeffrey. 2012. "Ethan Marcotte on Responsive Web Design "http: //www.netmagazine.com/interviews/ethan-marcotte-responsive-web-design diakses 25 Maret 2016. 
ISSN : 2503-054X

Jurnal Ilmu Komputer \& Teknologi Informasi 